\title{
Can fearlessness come in a tiny package?
}

\section{A molecule called microRNA-153 helps to prevent rats associating new environments with fear.}

\section{BRYAN W LUIKART}

Related research article Mathew RS,

Tatarakis A, Rudenko A, Johnson-Venkatesh

EM, Yang YJ, Murphy EA, Todd TP,

Schepers ST, Siuti N, Martorell AJ, Falls WA,

Hammack SE, Walsh CA, Tsai LH, Umemori

H, Bouton ME, Moazed D. 2016. A

microRNA negative feedback loop

downregulates vesicle transport and inhibits

fear memory. eLife 5:e22467. doi: 10.7554/

elife.22467

(c) Copyright Luikart. This article is distributed under the terms of the Creative Commons Attribution

License, which permits unrestricted use and redistribution provided that the original author and source are credited. it will become "frozen with fear" even if no shock is delivered.

Two regions of the brain - the amygdala and the hippocampus - have major roles in the formation of fear-associated memories. The experience of fear increases neuronal activity in several regions of the amygdala, and learning about a new environment increases activity in the hippocampus (Phillips and LeDoux, 1992). Stable associative memories are formed by changing the strength of the connections between neurons - called synapses - in these two regions.

To communicate across synapses, the presynaptic neuron releases neurotransmitters from membrane-enclosed compartments called vesicles in a process called exocytosis. The neurotransmitter molecules then travel across the synapse and bind to receptors on the surface of the postsynaptic neuron. The strength of the synapse can be changed by altering the ability of the presynaptic neuron to release neurotransmitters, or by altering the availability of the receptors on the postsynaptic neuron (Kessels and Malinow, 2009; Nicoll and Schmitz, 2005). Now, in eLife, Danesh Moazed of Harvard Medical School and colleagues including Rebecca Mathew and Antonis Tatarakis as joint first authors - report that the synapses responsible for the formation of fearassociated memories are kept in check by a tiny molecule called microRNA-153 (Mathew et al., 2016).

MicroRNAs are short RNA molecules (Lee et al., 1993; Wightman et alo, 1993) that interfere with the ability of messenger RNA molecules to encode proteins (Selbach et alı, 2008). Mathew et al. - who are based at 
Harvard and a number of other institutes in the United States - identified a set of 21 microRNAs whose production is increased by fear conditioning in rats. In particular, they found that learning to associate fear with a new environment caused the expression of microRNA-153 to increase by a factor of approximately four in a part of the hippocampus called the dentate gyrus.

To determine whether microRNA-153 has a role in the formation of fear-associated memories Mathew et al. reduced its production in the hippocampus and performed fear conditioning experiments. They found that rats that were deficient in microRNA-153 froze more often in the cage where they had experienced an electrical shock. Thus, it appears that microRNA-153 decreases the formation of fear-associated memories.

To determine how microRNA-153 inhibits the formation of fear memories, Mathew et al. analyzed all of the genes that they had predicted would be regulated by fear-induced microRNAs. This sample included a large proportion of the genes involved in vesicle exocytosis, and microRNA-153 targeted a large number of these genes. Further investigation revealed that fear conditioning reduced the expression of the exocytosis-related genes, and microRNA-153 knockdown increased their expression.

Genes regulated by microRNA-153 (such as Snap25 and Pclo) control synaptic strength by regulating both presynaptic vesicle exocytosis and postsynaptic receptor trafficking (Jurado et al., 2013; Südhof, 2013). By demonstrating in vitro that manipulating the expression of microRNA-153 can also regulate these processes, Mathew et al. conclude that microRNA153 counteracts the formation of associative memories during fear conditioning by decreasing the strength of synapses.

The results also lead to a number of new questions. Does microRNA-153 regulate the activity of the hippocampus more generally? And is microRNA-153 expression regulated in other brain regions, such as the amygdala, to modulate other aspects of fear?

It is also important to note that Mathew et al. found a total of 21 microRNAs whose production increased as a result of fear conditioning. Based on their sequence, these microRNAs are predicted to target genes involved in a number of processes: vesicle fusion, neuronal development, long-term potentiation, neurotransmission and synaptogenic adhesion. Thus, figuring out how these microRNAs influence memory formation is likely to involve a number of mechanisms that were not investigated by Mathew et al.
Finally, as we gain insight into the roles that microRNAs play, it may be possible to leverage the properties of these tiny molecules to develop new treatments for anxiety and other disorders.

Bryan W Luikart is at the Geisel School of Medicine, Dartmouth College, Hanover, United States Bryan.W.Luikart@dartmouth.edu (iD) http://orcid.org/0000-0002-3181-6075

Competing interests: The author declares that no competing interests exist.

Published 06 February 2017

\section{References}

Jurado S, Goswami D, Zhang Y, Molina AJ, Südhof TC, Malenka RC. 2013. LTP requires a unique postsynaptic SNARE fusion machinery. Neuron 77: 542-558. doi: 10.1016/j.neuron.2012.11.029, PMID: 23395379

Kessels HW, Malinow R. 2009. Synaptic AMPA receptor plasticity and behavior. Neuron 61:340-350. doi: 10.1016/j.neuron.2009.01.015, PMID: 19217372 Lee RC, Feinbaum RL, Ambros V. 1993. The C. elegans heterochronic gene lin- 4 encodes small RNAs with antisense complementarity to lin-14. Cell 75:843-854. doi: 10.1016/0092-8674(93)90529-Y, PMID: 825262 Maren S, Phan KL, Liberzon I. 2013. The contextual brain: implications for fear conditioning, extinction and psychopathology. Nature Reviews Neuroscience 14 417-428. doi: 10.1038/nrn3492, PMID: 23635870 Mathew RS, Tatarakis A, Rudenko A, JohnsonVenkatesh EM, Yang YJ, Murphy EA, Todd TP, Schepers ST, Siuti N, Martorell AJ, Falls WA, Hammack $\mathrm{SE}$, Walsh CA, Tsai LH, Umemori H, Bouton ME, Moazed D. 2016. A microRNA negative feedback loop downregulates vesicle transport and inhibits fear memory. elife 5:e22467. doi: 10.7554/eLife.22467, PMID: 28001126

Nicoll RA, Schmitz D. 2005. Synaptic plasticity at hippocampal mossy fibre synapses. Nature Reviews Neuroscience 6:863-876. doi: 10.1038/nrn1786, PMID: 16261180

Phillips RG, LeDoux JE. 1992. Differential contribution of amygdala and hippocampus to cued and contextual fear conditioning. Behavioral Neuroscience 106:274285. doi: 10.1037/0735-7044.106.2.274, PMID: 1590 953

Selbach M, Schwanhäusser B, Thierfelder N, Fang Z, Khanin R, Rajewsky N. 2008. Widespread changes in protein synthesis induced by microRNAs. Nature $\mathbf{4 5 5}$ : 58-63. doi: 10.1038/nature07228, PMID: 18668040 Südhof TC. 2013. Neurotransmitter release: the last millisecond in the life of a synaptic vesicle. Neuron $\mathbf{8 0}$ : 675-690. doi: 10.1016/j.neuron.2013.10.022, PMID: 24183019

Wightman B, Ha I, Ruvkun G. 1993. Posttranscriptional regulation of the heterochronic gene lin-14 by lin-4 mediates temporal pattern formation in $C$. elegans. Cell 75:855-862. doi: 10.1016/0092-8674(93)90530-4, PMID: 8252622 